UDC 339.748.3(477:061.1EC) DOI: https://doi.org/10.31617/zt.knute.2020(109)07

HELLYER Mark Director of CTA Economic \& Export Analysts

(UK), postgraduate student,

E-mail: markhellyer@me.com Kyiv National University of Trade and Economics

ORCID: 0000-0001-5665-4052 Kyoto str., Kyiv, 02156, Ukraine

\title{
EFFECT OF UKRAINE'S EXCHANGE RATE DEVALUATION ON TRADE WITH THE EU
}

This article examines the relationship between exchange rate changes and export development within the context of the free trade agreement (DCFTA) between Ukraine and the EU. It argues that the effects of the exchange rate may be a greater influence than the FTA regime itself. After examining current theory and definitions, the article looks at difference measures of exchange rate, nominal, variations of the real exchange, exchange rate volatility and equilibrium exchange rate to identify causal links to Ukraine's trade before and after the DCFTA. It shows that there is a positive causal relationship between the real exchange rate and exports with devaluations during implementation had a significant impact on Ukraine's exports, and this effect is greatest on those products that benefited from better access under the FTA.

Keywords: trade liberalization, the Deep and Comprehensive Free Trade Area, economic growth, currency regulation, currency exchange rate regime, exports, preferential trade agreements.

Хеллаер М. Влияние девальвации обменного курса Украины на торговлю c EC. В статье рассмотрена взаимосвязь между изменением валютного курса и развитием экспорта в контексте соглашения о свободной торговле (УВЗСТ) между Украиной и ЕС. Валютный курс может иметь большее влияние, чем сам режим ЗСТ. Учитывая современные теории и определения, в статье проанализированы различные подходы $\kappa$ определению обменного курса, номинальная стоимость, вариачии реального обмена, изменчивость валютного курса $u$ равновесный обменный курс для выявления причинно-следственных связей $с$ торговлей Украины до и после УВЗСТ. Это свидетельствует о наличии положительной причинно-следственной связи между реальным обменным курсом и экспортом с девальвацией во время внедрения, что существенно повлияло на экспорт Украинь, и этот эффект является крупнейшим для тех товаров, которые получили преимущество от лучщего доступа к ЗСТ.

Ключевые слова: либерализация торговли, углубленная и всеобъемлющая зона свободной торговли, экономический рост, регулирование валюты, режим валютного курса, экспорт, льготные торговые соглашения.

Background. The economic integration of Ukraine with the EU under the AA/DCFTA seeks to provide open market entry and legislative alignment to the Single European Market through improved market access (gradually eliminating tariffs) and regulatory alignment (Ukraine adopting EU business regulations so that there is no difference in applied regulations for a Ukrainian business whether the product is sold in Ukraine or in the

(C) Hellyer M., 2020 
EU). However, the AA/DCFTA does not address exchange rate stability whereby rates are linked so that it creates improved trade opportunities throughelimination of transaction costs and exchange rate uncertainty and increase in price transparency.Greater exchange rate stability should result in lower transaction costs and price transparency that reduce costs and thereby enhance competition and increase international competitiveness of enterprises leading to greater trade.

Moreover, in the absence of exchange rate linkages in the agreement, the relative value of the exchange rate between EU and Ukraine could affect trade and potentially negate any of the benefits derived from market access improvements. Overvalued currencies make imports relatively cheaper and exports relatively expensive encouraging imports and discouraging exports. Therefore, devaluation of a national currency would lead to a reversal of the situation and balanced trade.

The object of this Paper is to understand how the exchange rate between the UAH and the euro affected exports to the EU under the DCFTA and constrained or enhanced performance: whether at a nominal level, real exchange rate, exchange rate uncertainty and/or real exchange rate misalignment. In addition, do these effects affect different groups of Ukraine's exports in different ways and how much of Ukraine's export performance to the EU post DCFTA is affected by exchange rate changes. This is not only interesting within the context of the DCFTA policy itself, but also in terms of the Central Bank of Ukraine's policy of controlled liberalisation from dollar tracking in the post DCFTA period.

Analysis of recent research and publications. Although Ukraine's exchange rate has been studied in recent years in terms of the wider impact on the economy and a more broader discussion on the method of management of the exchange rate itself, for example see [1-5], very little analysis of the impact of Ukraine's exchange rate on trade specifically has been undertaken. Prior to 2014, both practical and theoretical literature focused on the effects of artificially maintaining the exchange rate such as Vorobyov [6] who used PPP method of real exchange rate to show that the UAH was overvalued and adversely affected the macro-economic fundamentals, including trade balance but concluded that although devaluation was necessary, social consequences may lead to further supporting currencies rather than devaluing (as in the case of Argentina and Brazil) and therefore, there is a need to study the wider effects of devaluation first before embarking on such policies.

After the devaluations experienced in Ukraine from 2014, scientific study in Ukraine also examined the effects of the volatility and fluctuations of the exchange rate on the wider economy. Didur et al [7] examines the causes of instability in the UAH exchange rate and postulates that this instability increases uncertainty and risk for business and therefore recommends control of the currency (managed floating) but provides no analysis of real effects. 
Gorraya [8] showed using presentation of data and correlations, that unpredictable exchange rate fluctuations can be extremely negative on the national economy, causing inflation, growth risks of international trade and investment attraction, exacerbation of currency risk in the banking sector and currency speculation.

However, these studies have largely examinedthe theoretical framework and/or observations of trends, for determining the effects of exchange rate devaluations and volatility on exports. Thesedo not explicitly examine the effects of the exchange rate on the effectiveness exports and especially under the DCFTA provisions, so a broader analysis of literature on exchange rate effects on trade is needed.

Within the EU, Monetary Union extends to a common currency and creates one of the most advance and integrated monetary unions in the world. The trade effects of the Eurozone monetary union have been studied and have been shown to have had a mostly positive effect on EU trade. Early estimations from Micco et al. [9] found 5-10\% increase in bilateral trade but later studies for example, Bun and Klaassen [10] suggests only a $3 \%$ increase in trade.

However, Johnson argues [11] that devaluations can only be effective if there are real devaluations; that is, if the relative price of tradeables is devalued. Johnson examined the effect on the economy, in terms of tradable (imports/exports) and non-tradeables (domestic production and consumption). He concluded that a large real devaluation could cause a nominal increase in exports and decrease in imports.

Kreinin [12] examines the «pass through» effects of real exchange rate changes on import and export prices and then the consequent impact on import and export volumes. The methodology applied by Kreinin is that of a «control» country approach' whereby the «passthrough» effect is the difference between the changes in price that actually has taken place in the country investigated and the hypothetical change that would have occurred in the absence of exchange rate devaluations (measured by a set of control countries where no exchange rate change occurred). The results of this study showed that devaluations caused a significant effect on volumes of trade in 3 of the 6 countries investigated. For example, a $10 \%$ devaluation (with $100 \%$ pass through to export prices) in the US, generated a $17 \%$ increase in exports (equivalent to an estimated foreign demand elasticity for US exports of 1.7). implied foreign demand elasticities for Japanese and Canadian exports were 1.1 and 2.3 respectively.Bhagwat and Onitsuka [13] examined 22 nominal devaluations in 19 countries. Growth rates and market shares before and after the devaluation showed that most countries experienced an increase in export growth over a three-year period with even better results from an analysis of individual commodities.

Yandle and Ridler [14] developed a simplified model of world markets for commodities from developing countries to assess the impact of exchange rate changes on export growth and suggests that export responses 
to devaluation's is likely to be insignificant due to export supply rigidity such as low opportunity costs for capital, labour, land and technology which limits supply responses.Little et al [15] examined 18 countries and showed that there is no impact of real devaluations on traditional agricultural and mineral exports. However, there was a marked improvement in exports of non-traditional/manufactured products as a result of real exchange rate devaluations.

The aim of the article is to investigate the impact of Ukraine's currency devaluation on exports to the EU under the DCFTA to see the extent of the impact on change in trade due to devaluation as opposed to improved DCFTA market access conditions.

Materials and methods. Methods of analysis and synthesis, method of statistical analysis and OLS regression modelling are used in the article. The research based on export data from the European Union at a product level, the World Bank Indicators on Exchange rate and the European Union-Ukraine Association Agreement text.

Results. In the review of scientific literature, different measures of real exchange rate and the use of different measures has be shown to affect the results including Fleissig and Grennes's[16]; Sadoulet and Janvry [17] and Vries [18]. These have shown that different calculations of a countries' real exchange rate can lead to significantly different results. In many cases the direction of the change in real exchange rate has been shown to be opposite using differing indices, as well as differing definitions. Therefore, several authors have adopted an alternative examination of exchange rate as a policy by studying the equilibrium real exchange rate at the impact of misalignment and realignment on international trade. One of the first studies on misalignment of the real exchange rate was conducted by Edwards [19] who conclude that "disequilibrium in the real exchange rate can reduce economic efficiency, misallocate resources, undermine the agricultural sector and increase capital flight". Misalignment theory states that if the real exchange rate is overvalued, then imports will be cheaper and exports more expensive, encouraging imports at the expense of local production and discouraging exports and a reallocation of resources to domestic industries. Although a devaluation from equilibrium should still theoretically cause an increase in exports and a decrease in imports, in developing countries, there is generally a minimum level of imports required of essential items not produced locally. In addition, exporters would be encouraged to stop exporting and produce import substituting products which are attracting higher prices. Thus, a country should aim for a policy of equilibrium real exchange in order to encourage export development.

Edwards used simple regressions of exchange rate misalignment to model the impact on growth of GDP on 12 countries. This showed that countries with large and persistent real exchange rate misalignment experienced poor economic performance relative to those with real exchange rates close to the equilibrium value. 
In order to estimate the extent of misalignment of the real exchange rate, the difference between the equilibrium real exchange rate and the current real exchange rate is measured. This can be used using an elasticity approach to calculate the misalignment. The level of exports and imports generated with the Equilibrium Real Exchange Rate (ERER) can be determined through the movement from the real exchange along the supply and demand curves(Supply and Demand Movements to Equilibrium Real Exchange Rate):

$$
\frac{Q-E}{E}=s_{E}\left(\frac{E R E R-R E R}{\pi E R}\right)
$$

where $\varepsilon_{E}$ is the export elasticity.

$$
\frac{M-Q}{M}=s_{M}\left(\frac{E R E R-R E R}{R E R}\right)
$$

where $\varepsilon_{M}$ is the import elasticity.

According to Sadoulet and Janvry [20] an «acceptable or sustainable» level of trade deficit will generate the equilibrium real exchange rate. Therefore, $E^{*}$ and $M^{*}$ (the level of imports and exports for a sustainable trade deficit). Substituting $\mathrm{E}^{*}$ and $\mathrm{M}^{*}$ in the above equations for $Q$, and combining the simultaneous equations the following equation is produced (Calculating Real Exchange Rate):

$$
\left(\boldsymbol{M}-\boldsymbol{M}^{*}\right)-\left(E-E^{*}\right)=\left(\boldsymbol{s}_{E^{*}} E-\boldsymbol{s}_{M F^{*}} \boldsymbol{M}\right)\left(\frac{E R E R-R E R}{R \cdot E R}\right)
$$

Since, $M-E$ is the actual deficit $(D)$ and $M^{*}-E^{*}$ is the acceptable deficit $\left(D^{*}\right), D$ and $D^{*}$ can be substituted and the equation solved for ERER as follows (Equilibrium Real Exchange Rate Estimation):

$$
E R E R=R E R\left[1+\frac{(D-D)}{\left(\varepsilon_{E} E-\varepsilon_{M} M\right.}\right]
$$

Once an acceptable level of deficit has been determined, which according to Sadoulet and Janvry, is two per cent of GDP, the equilibrium real exchange rate can be calculated.

Based on the theoretical framework of the effect of the exchange rate (deliberate policy or not) this chapter explores whether the change in value of the Ukrainian hryvnia affected exports to the EU, did exchange rate uncertainty play any role and/or did the relative over or undervaluation of UAH) constrain or otherwise impact trade with EU under the DCFTA.

The economic literature demonstrated that devaluations can only be effective if there are real devaluations, that is, if the relative price of 
tradeables is devalued, if there were in fact no «real» devaluations, this could explain why there are positive correlations between the nominal Euro/UAH rate and some of the groups of Ukraine's exports to the EU.

In order to understand the extent to which the appreciation or depreciation in the UAH had on Ukraine's export performance, a model of trade and real exchange rate is developed. Much of the literature explains this as not only is the change in nominal exports affected by supply responses, but also by demand and exchange rate uncertainty or volatility that also impact on investment by entrepreneurs. EU demand response could explain the more positive effects seen in agricultural products that had tariff barriers or equivalent preDCFTA application showing a price elasticity effect and post 2014, there was no real exchange correlation but this group saw a positive increase in exports to EU which may mean the tariff liberalisation effect was greater on this group.

In addition to this, the contention by many economists (especially those arguing against flexible exchange rate regimes) is that an unstable exchange rate has an adverse effect on trade and investment through increasing risks. According to the IMF [21] countries exchange rate policies should avoid «jerky movements in the real exchange rate and overvaluation (...) as they have adverse effects on the tradable sector»!.

The World Bank [22] used a simple model to examine the impact of exchange rate changes in trade.

«Simple export equations are estimated in which the explanatory variables include the real exchange rate, uncertainty in exchange rate and world demand for exports. Exchange rate uncertainty is approximated by a two-year moving variance (...) currency devaluation encourage exports».

The World Bank's model is specified as follows:

$$
\ln X_{t}=a_{0}+a_{1} \cdot \ln R E R_{t}+a_{2} \ln E R U_{t}+a_{8} \ln W D_{t}
$$

Variables: $R E R$ - real exchange rate $(1985=100)$;

$E R U$ - real exchange rate uncertainty, approximated by two-year moving average variance;

$W D$ - world demand, estimated by using OECD GDP at constant prices;

$X-$ nominal value of exports.

In order to examine the potential role (if any) of the exchange rate in Ukraine's export performance to the EU, this the model was re-specified with a more targeted approach:

$$
\ln X_{t}=a_{0}+a_{1}, \ln R E R_{t}+a_{2} \ln E R U_{t}+a_{g} \ln E U D_{t}
$$

Variables: $R E R$ - real exchange rate;

$E R U$ - real exchange rate uncertainty, approximated by two-year variance; $E U D-E U$ demand, estimated by using EU GDP at constant prices;

$\mathrm{X}$ - nominal value of exports to the EU. 
Ukraine has for a long time maintained a fixed exchange rate policy with central bank and the Ministry of Finance, «tracking» and intervening in currency markets (buying and selling currency). Ukraine kept the UAH exchange rate tied to the US dollar [16] under open economy conditions, causing huge imbalances in foreign trade, financial sector, and economic motivation of citizens and companies. As a result, from 2010-2013, Ukraine used almost half of its currency reserves to maintain the exchange rate, so that in late 2013 reserves amounted to only USD 20 billion (35\% of short-term debt and 2.5 months of imports). Additional external borrowings were needed and a USD 3 billion loan ("Eurobonds") from Russia was taken. However, the situation continued to deteriorate as the National Bank of Ukraine struggled to maintain a fixed rate with gradual and small devaluations until February 2014 when it allowed the UAH to devalue in one day from $16 \mathrm{UAH} / \mathrm{USD}$ to $25 \mathrm{UAH} / \mathrm{USD}$.

Between 2014 and 2015, the National Bank of Ukraine continued managing the exchange rate with subsequent larger depreciations of $14 \%$ to $19.5 \%$ monthly and then to $30 \%$ in March 2015. At the same time, it imposed severe restrictions on the purchase of foreign currency. Therefore, since 2014, Ukraine has pursued a policy of «controlled» exchange liberalisation that has aimed at gradual devaluation whilst maintaining stability until the currency liberalisation can be fully achieved through «integration into the European economic and financial space that will allow Ukraine to become a full-fledged participant of the globalized economy» [13].

These two policy approaches can be described as «fixed» pre 2014 and «controlled liberalisation» post 2014 and this exchange rate policy shift coincides with the AA/DCFTA implementation. Therefore, this nominal «devaluation» could provide a stimulus for trade with the EU. This paper examines the effect of Ukraine's exchange rate policy on trade with the EU under the DCFTA to see if either, relative valuation of the exchange affected trade and whether the lack of exchange rate integration (either tracking or fixed) would potentially increase the trade under the agreement. This is not only important from the perspective of national exchange rate policies (fixed versus managed floating) but also in understanding whether the relatively poor performance of exports under the DCFTA has been affected, either positively or negatively by the exchange rate.

Ordinary Least Squares regression analysis was undertaken for Ukraine exports to the EU, disaggregated into total, agricultural and nonagricultural exports, and further disaggregated in above categories for preferred exports (those groups of products that gained preferences under the DCFTA and outperformed other groups).

Nominal values of export were used as the dependent variable with explanatory variables of real exchange rate against the euro, EU real GDP and real exchange rate, two year variance as a measure of exchange rate uncertainty Table 1 below summarises the results of the regressions. 
Model of Exchange Rate Impact on Ukraine's Exports to EU

\begin{tabular}{|l|c|c|c|c|c|c|}
\hline $\begin{array}{l}\text { Coefficients } \\
\text { (T-statistic) }\end{array}$ & $\begin{array}{c}\text { Total } \\
\text { XEU }\end{array}$ & $\begin{array}{c}\text { Total Ag } \\
\text { XEU }\end{array}$ & $\begin{array}{c}\text { Total } \\
\text { Non Ag } \\
\text { XEU }\end{array}$ & $\begin{array}{c}\text { Preferred } \\
\text { XEU }\end{array}$ & $\begin{array}{c}\text { Preferred } \\
\text { Ag XEU }\end{array}$ & $\begin{array}{c}\text { Preferred } \\
\text { Non Ag } \\
\text { XEU }\end{array}$ \\
\hline Intercept & $\begin{array}{c}735.98 \\
(2.10)\end{array}$ & $\begin{array}{c}1858.20 \\
(2.65)\end{array}$ & $\begin{array}{c}457.84 \\
(1.02)\end{array}$ & $\begin{array}{c}832.23 \\
(3.26)\end{array}$ & $\begin{array}{c}856.47 \\
(2.10)\end{array}$ & $\begin{array}{c}638.85 \\
(2.30)\end{array}$ \\
\hline RER (WPI) & -1.59 & $\begin{array}{c}-4.27 \\
(-2.07)\end{array}$ & $\begin{array}{c}-0.90 \\
(-2.78)\end{array}$ & $\begin{array}{c}-2.07 \\
(-3.92)\end{array}$ & $\begin{array}{c}-2.31 \\
(-2.59)\end{array}$ & $\begin{array}{c}-1.42 \\
(-2.33)\end{array}$ \\
\hline ERU & $\begin{array}{c}0.01 \\
(0.92)\end{array}$ & $\begin{array}{c}0.08 \\
(2.53)\end{array}$ & $\begin{array}{c}0.00 \\
(-0.10)\end{array}$ & $\begin{array}{c}0.01 \\
(1.11)\end{array}$ & $\begin{array}{c}-0.01 \\
(-0.61)\end{array}$ & $\begin{array}{c}0.04 \\
(3.35)\end{array}$ \\
\hline EUD & -27.87 & -71.80 & -17.00 & -31.74 & -32.73 & -24.17 \\
\hline Adjusted R & $(-2.04)$ & $(-2.62)$ & $(-0.97)$ & $(-3.18)$ & $(-0.61)$ & $(-2.22)$ \\
\hline DW & 0.20 & 0.70 & -0.21 & 0.92 & 0.91 & 0.68 \\
\hline
\end{tabular}

Source: author's Calculations Based on Eurostat Data.

The coefficients of real exchange rate are all negative, as expected showing that a depreciation in the UAH contributed to an increase in exports to the EU of each group of products. In addition, the real exchange rate coefficient was significant (t-statistic $> \pm 1.86$ with $95 \%$ confidence) in all models of Ukraine's exports except for total non-agricultural exports, suggesting in this case that the real exchange rate does not affect these exports.

Exchange rate uncertainty was only significant for total agricultural exports and preferred non-agricultural exports, but even in these cases, the coefficient was close to zero suggesting uncertainty in currency plays little or no role in exports to EU.

EU demand was significant in 4 of the 6 models, but not significant for total non-agricultural exports and preferred agricultural exports. Moreover, contrary to expectations, all coefficients of EU demand were negative.The coefficient of EU demand would also be expected to be positive as demand for Ukrainian products in the EU would rise as EU income rises. However, traditional economic theory [24] states that income elasticity of demand may be either positive or negative and these have been used to classify products into «normal» or «inferior goods» or into «necessities» or «luxuries". If as a result of an increase in income the quantity demanded of a particular product decreases, it would be classified as an «inferior» good. However, generally this would not be expected at anaggregate level as it would suggest that on balance, the structure of Ukraine's exports is comprised mainly of «inferior» goods that as EU income rises, are demanded less.

In terms of goodness of fit (adjusted $\mathrm{R}^{2}$ ), the models were quite disappointing for total trade groupings (total, agriculture and nonagricultural exports) with only total agricultural exports producing a good model. Preferred exports models were a much better fit so that the 
disaggregated models of exchange appear better which follows the findings of a number of studies such as Goldstein and Khan [25], modelling overall trade flows constrains the elasticity's of all explanatory variables as it assumes them to be equal across all sectors. Their study demonstrates that due to the varying markets in which trade occurs, in particular between primary and manufactured products, the aggregation bias is significant. Bhagwat and Onitsuka [13] also saw improved results from examining real exchange changes and impact on trade performance of individual products.

Also, in all the above exchange rate models, the presence or not of autocorrelation is inconclusive which contain mean: with 3 variables and 8 observations, the Durbin Watson statistic lower and upper limits range (inconclusive) and is $0.37-1.713$ and 2.287-3.63 (normal range 1.7132.287). Therefore, the standard errors for the explanatory variables could be underestimated which risks some coefficients appearing significant when they are not and so the model results may not be reliable.

Whilst the exchange rate models indicate that the devaluation in the UAH may have had a significant effect on Ukraine's exports to the EU (with average elasticities of real exchange appreciation of -2.1 across the different groups of products), economic theory suggests that if a currency is overvalued, the price elasticity effect of a devaluation (even real exchange rates) will be limited. If the UAH is overvalued, the EU has the opportunity to choose to import from other cheaper third countries (in terms of tariff and/or currency value) over Ukraine, despite the real devaluation. Therefore, understanding the potential misalignment between the real exchange and equilibrium real exchange rate of the Euro/UAH may lead to better linkages to exports to the EU. Equally, an undervaluation can also have negative effects on economic activity and exports, thus, in these cases, correlation between exports and the real exchange rate may produce an inconsistent sign for the parameters or no correlation at all. Exchange rate misalignment analysis therefore, is a better approach to exchange policies as it examines the impact of positive and negative misalignment and does not simply assume overvaluation or that a devaluation will always lead to price elasticity effect.

Misalignment is measured by the magnitude of the difference between the equilibrium real exchange rate and the actual real exchange rate in each time period:

$$
\boldsymbol{H}=\frac{E R E R \pi R R}{R E R}
$$

Substituting for the equilibrium real exchange rate, we expand the equation of misalignment thus:

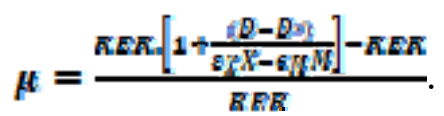


Expanding the numerator, we can eliminate RER:

$$
\begin{gathered}
k=\left[1+\frac{(D-D *)}{s_{X} X-\epsilon_{W} M}\right]-1 \\
F=\left[\frac{(D-D *)}{s_{X} X-\epsilon_{M} M}\right]_{t}
\end{gathered}
$$

where: $\mu$ - Real Exchange Rate misalignment (in percentage as absolute number);

$E R E R$ - The equilibrium real Exchange Rate;

$R E R$ - Real Exchange Rate;

$D$ - The trade deficit with the EU, Ukraine's exports to the EU less Ukraine's imports from the EU;

$D^{*}$ - The sustainable trade deficit is generally measured as 2 per cent of GDP (Sadoulet and Janvry[18]);

$\varepsilon$ - The elasticities of export and import demand have been generalised based on findings throughout the literature. According to Sadoulet and Janvry [Ошибка! Закладка не определена.], rates of -2 and 1 for import and export demand respectively, although Khan and Ostry [26] used much lower rates for import elasticities of between 1 and -0.5 ;

$X$ - Ukrainian exports to the EU;

$M$ - Ukrainian imports from the EU.

Estimates for Misalignment of the UAH against the Euro are summarised below in Table 2.

Table 2

Ukraine Exchange Rate Misalignment, \%

\begin{tabular}{|l|c|c|}
\hline \multirow{2}{*}{\multicolumn{1}{c|}{ Time Period }} & \multicolumn{2}{|c|}{ Average Overvaluation } \\
\cline { 2 - 3 } & saudolet assumptions & khan assumptions \\
& $E_{x}=1 ; E_{m}=-2$ & $E_{x}=1 ; E_{m}=-1$ \\
\hline Pre DCFTA & 9,2 & 21,5 \\
Post DCFTA & 2,0 & 4,2 \\
Period average & 5,6 & 12,9 \\
\hline
\end{tabular}

Note: negative values would indicate the currency is undervalued.

Source: futhor's Calculations Based on Eurostat Data.

Analysing the whole period (2010-2017), the UAH has been shown to be significantly overvalued in both definitions, and as expected more overvalued pre DCFTA when the Central Bank of Ukraine was tracking the dollar and effectively fixing the exchange rate than post DCFTA period.

Examining the annual data for misalignment shows that there was an undervaluation of the UAH in 2015 (the first year of liberalisation) which 
suggests that policy makers overcompensated initially but generally, as the exchange now is managed (albeit in a more liberal way) has meant that the post DCFTA overvaluation of UAH was between $2.0-4.2 \%$; this may be larger than average tariffs preferences received for many products and may explain why the exchange rate models were not effective at explaining Ukrainian exports to the EU as the UAH was on average between $5.6 \%$ and $12.9 \%$ overvalued across the whole period.

The two assumptions used for import elasticity of demand produce different results as to the size of misalignment. The Sadoulet assumption of elasticity produces smaller estimates of misalignment than the Khan assumption. As to which of the assumptions is better, it is not generally possible to define which is better using calibration methods as it is largely subjective. Also, the elasticities will be different for each product and therefore different yearly on an aggregate level as the structure of exports can change.

A period average misalignment does not accurately examine the relationship between change in exchange rate misalignment and change in export performance on an annual basis over the period. To obtain a true picture as to whether there is any correlation between misalignment and export performance, regression analysis was undertaken using an adapted exchange rate model of EU demand for Ukrainian exports using exchange rate misalignment instead of real exchange rate. An average misalignment was used (average of Sadoulet and Khan estimates). As the size of exchange rate misalignment gets smaller, exports would be expected to increase as the value of exchange and products approaches equilibrium.

In order to examine the potential role (if any) of the exchange rate misalignment in Ukraine's export performance to the EU, this the exchange rate model was re-specified:

$$
\ln X_{t}=a_{0}+a_{1} \cdot \ln _{t}+a_{2} \ln E R U_{t}+a_{3} \ln E U D_{t}
$$

Variables: $\mu$ - real exchange rate misalignment (absolute \%), whether under or overvalued;

$E R U$ - real exchange rate uncertainty, approximated by two-year variance;

$E U D$ - EU demand, estimated by using EU GDP at constant prices; $X$ - nominal value of exports to the EU.

Ordinary Least Squares regression analysis was undertaken for Ukraine exports to the EU, disaggregated into total, agricultural and nonagricultural exports, and further disaggregated in above categories for preferred exports (those groups of products that gained preferences under the DCFTA and outperformed other groups).

Nominal values of export were used as the dependent variable with explanatory variables of real exchange rate misalignment against the euro, EU real GDP and real exchange rate, two-year variance as a measure of 
exchange rate uncertainty. Table 3 below summarises the results of the regressions.

Table 3

Exchange Rate Misalignment and Exports

\begin{tabular}{|l|c|c|c|c|c|c|}
\hline $\begin{array}{l}\text { Coefficients } \\
\text { (T-statistic) }\end{array}$ & $\begin{array}{c}\text { Total } \\
X E U\end{array}$ & $\begin{array}{c}\text { Total } \mathrm{Ag} \\
X E U\end{array}$ & $\begin{array}{c}\text { Total } \\
\text { Non } \mathrm{Ag} \\
X E U\end{array}$ & $\begin{array}{c}\text { Preferred } \\
X E U\end{array}$ & $\begin{array}{c}\text { Preferred } \\
A g X E U\end{array}$ & $\begin{array}{c}\text { Preferred } \\
\text { Non } A g \\
X E U\end{array}$ \\
\hline Intercept & $-41,85$ & $-279,99$ & 26,97 & $-192,64$ & $-283,79$ & $-67,55$ \\
$(-0,78)$ & $(-2,88)$ & $(0,45)$ & $(-4,16)$ & $(-4,34)$ & $(-1,70)$ \\
\hline$\mu$ & 0,16 & 0,56 & 0,05 & 0,24 & 0,25 & 0,17 \\
& $(1,18)$ & $(2,31)$ & $(0,36)$ & $(2,07)$ & $(1,55)$ & $(1,76)$ \\
\hline$E R U$ & 0,03 & 0,13 & 0,00 & 0,03 & 0,01 & 0,06 \\
& $(1,04)$ & $(2,80)$ & $(0,01)$ & $(1,49)$ & $(0,32)$ & $(2,92)$ \\
\hline$E U D$ & 2,56 & 11,85 & $-0,15$ & 8,36 & 11,87 & 3,46 \\
& $(1,21)$ & $(3,10)$ & $(-0,06)$ & $(4,61)$ & $(4,63)$ & $(2,22)$ \\
\hline Adjusted $R^{2}$ & $-0,23$ & 0,63 & $-0,42$ & 0,83 & 0,92 & 0,57 \\
\hline DW & 2,12 & 2,37 & 2,12 & 2,36 & 2,98 & 2,48 \\
\hline
\end{tabular}

Source: author's Calculations Based on Eurostat Data.

Although the exchange rate coefficient was significant (t-statistic $> \pm 1.86$ with $95 \%$ confidence) in half the models on export to the EU (except total exports, total non-agricultural exports and preferred agricultural exports), the coefficients were all positive contrary to expectations. It should be expected that as the size of the misalignment of real exchange rate approaches the equilibrium level, exports should increase (that is negative coefficient).

Similarly, to the real exchange rate models of exports to the EU, exchange rate uncertainty coefficients are positive, instead of negative, and only significant in 2 of the six models; and even in these cases, the coefficients are close to zero indicating uncertainty is not a factor in exports to the EU. The real exchange rate models, EU demand was had a positive coefficient in 5 of the 6 models and 4 of these coefficients were significant.

As with the real exchange rate models of Ukraine's trade, only total agricultural exports and all preferred export group models had acceptable goodness of fit of model to dependent variable as measured by the adjusted $\mathrm{R}^{2}$. The presence of autocorrelation was inconclusive in 4 of the models; with 3 variables and 8 observations, the lower and upper limits range (inconclusive) is 0.37-1.713 and 2.287-3.63 (normal range 1.713-2.287). There is no autocorrelation in two models, but these both had negative adjusted $\mathrm{R}^{2}$, which means the models are not sufficiently explanatory of Ukrainian exports to the EU.

With inconclusive presence of autocorrelation and positive correlations for misalignment, meaning trade increases with greater misalignment of exchange rate, these models appear to be misspecified or, with relatively small coefficients for exchange rate misalignment (average 0.2 across the different groups of exports), exchange rate misalignment may not be a factor. 
The model could be misspecified through inaccurate measurement of the equilibrium exchange rate and therefore degree of misalignment is over or under estimated. For example, if $2 \%$ of GDP trade balance for equilibrium exchange is too liberal or too tight, then the degree of misalignment may be inaccurate.

It could also be that fundamentally tracking the equilibrium level may be flawed in the real world as imperfections in the market and movement in larger currencies of the world (US and European currencies) which are subject to speculation and are rarely in equilibrium themselves mean that it would be virtually impossible to find the true equilibrium rate and economic operators in the real economy would in any case not be able to react to such changes. Therefore, the model of real exchange rate impact of exports, subject to risk of autocorrelation that was inconclusive, appear more robust measures to understand effects of exchange rate on exports.

In order to estimate the actual impact of this real exchange rate devaluation of the Euro/UAH on Ukraine's exports post 2014, the real exchange models

were simulated using actual data for RER, ERU and EUD based on the OLS coefficients estimated above. In addition, to isolate the effect of real exchange to changes in Ukraine's exports, simulations were also holding

RER constant at 2013 levels and comparing the modelled results.

Table 4 shows a summary of the average annual simulated impact of the devaluation in UAH post DCFTA.

Table 4

\section{Average Annual Impact of RER Devaluation on Ukraine's Exports Post DCFTA (2014-2017), $€$ mn}

\begin{tabular}{|l|c|c|c|c|c|c|}
\hline \multicolumn{1}{|c|}{ Metric } & $\begin{array}{c}\text { Total } \\
X E U\end{array}$ & $\begin{array}{c}\text { Total } \mathrm{Ag} \\
X E U\end{array}$ & $\begin{array}{c}\text { Total } \\
\text { Non } \mathrm{Ag} \\
X E U\end{array}$ & $\begin{array}{c}\text { Preferred } \\
X E U\end{array}$ & $\begin{array}{c}\text { Preferred } \\
\mathrm{Ag} X E U\end{array}$ & $\begin{array}{c}\text { Preferred } \\
\text { Non } \mathrm{Ag} \\
X E U\end{array}$ \\
\hline $\begin{array}{l}\text { Actual Average } \\
\text { Annual Change }\end{array}$ & 712,4 & 395,5 & 316,9 & 319,9 & 293,0 & 25,4 \\
\hline $\begin{array}{l}\text { Simulated Average } \\
\text { Annual Change } \\
\text { (RER devaluation) }\end{array}$ & 135,1 & 372,6 & $-241,2$ & 229,7 & 264,0 & 17,1 \\
\hline $\begin{array}{l}\text { Simulated Average } \\
\text { Annual Change } \\
\text { constant RER }\end{array}$ & $-3158,3$ & $-856,6$ & $-2171,8$ & $-330,2$ & $-185,9$ & $-194,0$ \\
\hline $\begin{array}{l}\text { Simulated } \\
\text { Average Annual } \\
\text { Impact of RER } \\
\text { Depreciation }\end{array}$ & 3293,4 & 1229,3 & 1930,6 & 559,8 & 449,9 & 211,1 \\
\hline $\begin{array}{l}\text { Average Increase } \\
\text { in exports due to } \\
\text { RER, as \% exports }\end{array}$ & 6,26 & 6,79 & 5,12 & 7,30 & 8,26 & 5,68 \\
\hline
\end{tabular}

Source: author's Calculations Based on Eurostat Data. 
In all groups of products, the real exchange rate models showed that the devaluation of exchange rate had a positive impact on trade and without such devaluations, Ukraine's exports to the EU would have decreased over the post DCFTA period at both an aggregate and disaggregated level, and for both total and preferred groups of exports. This does not mean that other factors could not have positively influenced Ukraine's exports to the EU, and in fact given the difference between simulated and actual change in exports post DCFTA, this seems likely.

Conclusion. Based on the investigations, exchange rate uncertainty and exchange rate misalignment did not have any statistically significant impact on Ukraine's exports post AA/DCFTA. In all but one model, the coefficient for exchange rate uncertainty was not statistically significant and where it was significant (for total agricultural exports to the EU), the coefficient itself was close to zero. These means that fluctuations in exchange rate, that may have been thought to cause uncertainty amongst exports from Ukraine, have not had any impact on exports to the EU. This in itself is an important conclusion as often press and politicians have use volatility in exchange rate as a cause of Ukraine's relatively poor performance despite the DCFTA market access provisions.

Similarly, exchange rate misalignment (persistent over or under alignment between the difference between the equilibrium real exchange rate and the actual real exchange rate) caused by central bank interventions have led to higher than expected exchange rates of between $5.6 \%$ and $12.9 \%$ that have limited export responses (that is making Ukrainian exports more expensive in international markets). Misalignment was significant in half of the models but the coefficients were positive contrary to expectations (greater the misalignment, greater the exports). Given the tests for autocorrelation in all the models were inconclusive, these models appear to be misspecified or, with relatively small coefficients for exchange rate misalignment (average 0.2 across the different groups of exports), exchange rate misalignment is not a factor.

As shown in The contribution of the RER devaluations to total exports represent between $5.12 \%$ and $8.26 \%$ of Ukraine's average annual exports to the EU. The impact of exchange devaluation on Ukraine's exports to the EU is greater in the groups of preferred exports which performed better than aggregate total, agricultural and non-agricultural exports suggesting that this better performance is at least in some part due to the devaluation of the UAH. What is perhaps surprising is that in this group of preferred products, the exchange rate played a more significant role than for total and total disaggregated groups of exports as these exports the price effect of exchange rate is greater is preferred export groups suggests that in these products, the underlying price elasticity of demand is greater. This may be because preferred products are products that had been 
previously protected and are generally less complex/value added products (more for agriculture than non-agriculture) and therefore, have larger elasticities.

Table 5 below, the models of real exchange rate impact on Ukraine's exports to the EU show a consistent, significant and relatively large potential impact of devaluation of the UAH on exports, with average coefficients of -2.1 across different groups of Ukraine's exports meaning a $1 \%$ devaluation would increase exports by $2.1 \%$ and vice versa. With average annual devaluations of the Euro/UAH of $34 \%$ from 2014-2017, there is a strong potential impact post DCFTA of the exchange rate on trade.

The contribution of the RER devaluations to total exports represent between $5.12 \%$ and $8.26 \%$ of Ukraine's average annual exports to the EU. The impact of exchange devaluation on Ukraine's exports to the EU is greater in the groups of preferred exports which performed better than aggregate total, agricultural and non-agricultural exports suggesting that this better performance is at least in some part due to the devaluation of the UAH. What is perhaps surprising is that in this group of preferred products, the exchange rate played a more significant role than for total and total disaggregated groups of exports as these exports - the price effect of exchange rate is greater is preferred export groups suggests that in these products, the underlying price elasticity of demand is greater. This may be because preferred products are products that had been previously protected and are generally less complex/value added products (more for agriculture than non-agriculture) and therefore, have larger elasticities.

Table 5

Summary of Results

\begin{tabular}{|l|c|c|c|c|c|c|}
\hline \multicolumn{1}{|c|}{ Variables } & $\begin{array}{c}\text { Total } \\
X E U\end{array}$ & $\begin{array}{c}\text { Total } \mathrm{Ag} \\
X E U\end{array}$ & $\begin{array}{c}\text { Total } \\
\text { Non } \mathrm{Ag} \\
X E U\end{array}$ & $\begin{array}{c}\text { Preferred } \\
X E U\end{array}$ & $\begin{array}{c}\text { Preferred } \\
A g \text { XEU }\end{array}$ & $\begin{array}{c}\text { Preferred } \\
\text { Non } A g \\
X E U\end{array}$ \\
\hline $\begin{array}{l}\text { RER } \\
\text { Coefficients } \\
\text { (T-statistic) }\end{array}$ & $\begin{array}{c}-1,59 \\
(-2,07)\end{array}$ & $\begin{array}{c}-4,27 \\
(-2,78)\end{array}$ & $\begin{array}{c}-0,90 \\
(-0,92)\end{array}$ & $\begin{array}{c}-2,07 \\
(-3,70)\end{array}$ & $\begin{array}{c}-2,31 \\
(-2,59)\end{array}$ & $\begin{array}{c}-1,42 \\
(-2,33)\end{array}$ \\
\hline $\begin{array}{l}\text { Simulated } \\
\text { Average Annual } \\
\text { Impact of } R E R \\
\text { Depreciation }\end{array}$ & 3293,4 & 1229,3 & 1930,6 & 559,8 & 449,9 & 211,1 \\
$\begin{array}{l}\text { Average } \\
\text { Increase in } \\
\text { exports due to } \\
R E R, \text { as \% } \\
\text { exports }\end{array}$ & 6,26 & 6,79 & 5,12 & 7,30 & 8,26 & 5,68 \\
\hline
\end{tabular}

Source: author's Calculations Based on Eurostat Data.

${ }^{1}$ Difference between exports with devalued UAH and exports under Constant RER. 
Moreover, in both total agricultural and preferred agricultural export groups, the exchange rate impact of the devaluations was greater than for non-agricultural exports which means the price elasticity effect is greater in agricultural products which is to be expected as generally agricultural exports respond more to price sensitivities.

Overall, the liberalisation of the UAH that occurred simultaneously with the application of the DCFTA in Ukraine in 2014 seems to have a significant impact and positive contribution to Ukraine's export performance with the EU. For policy makers, the decision maybe whether or not the complete liberalisation of the exchange rate would lead to further devaluations as this is likely to lead to increased exports to the EU. However, as discussed above, this may have a bigger effect on more basic products rather than those with greater value added and therefore, policy makers may elect not to pursue such a policy as value added products with lower elasticities, especially those than rely on imported inputs would not be stimulated as much as basic goods.

However, from the simulated models, the impact of the exchange rate devaluations is higher in product groups that benefited from tariff liberalisation (preferred exports) that in total exports and therefore, the combined impact of the tariff liberalisation and exchange rate liberalisation could act as a greater stimulus to exports that either policy alone.

\section{REFERENCES}

1. Ilychok, B., \& Trevoho, O.(2016). Exchange Rate of Ukrainian Currency Trends And Potential Changes. Journal of Economics, Entrepreneurship, Management. (Vol. 3), 2 [in English].

2. Glushchenko, S., \& Tkalenko, S. (2016). Threats And Benefits of Exchange Rate Regimes for Ukraine in Terms of European Integration. Baltic Journal of Economic Studies. (Vol. 2), 2 [in English].

3. Bereslavska, O. (2015). Devaluation shocks and their consequences for Ukraine's economy. Economy and Forecasting. Issue 4, 29-42 [in English].

4. Piontkivsky, R. (1999). Exchange Rate Effects On The Current Account (Would The Devaluation Improve The Ukrainian Current Account). Kyiv: The National University of Kyiv-Mohyla Academy [in English].

5. Linnik, O. A. (2015). Formation of external state debt of Ukraine in 20102014: Causes and consequences. Regional Economics, 1, 104-114 [in English].

6. Vorobeva, K. O. (2010). Investigation of the influence of the high and low exchange rate on the economy of the country. Bulletin of the Academy of Customs Service of Ukraine, 1, 141-147 [in English].

7. Didur, S. V., Glukhova, V. I., \& Yeliseeva, O. Y. (2016). The Analysis of Tendencies of Fluctuation of the Exchange Rate in the Conditions of Crisis in Ukraine. Economy and Society. Issue 5 [in English]. 
8. Gorraya, L. O. (2016). The Influence of Volatility of The Exchange Rate on Selected indicators of Financial And Economic Development of Ukraine. Economic Sciences Bulletin of the Khmelnytsky National University, 4. (Vol. 1) [in English].

9. Micco, A., Luis O., G., Stein, E. \& Ordoòez, G. (2003). The Currency Union Effect on Trade: Early Evidence from EMU in Economic Policy. (Vol. 18). 315-356 [in English].

10. Bun, M. J. \& Klaassen, F. J. (2007). The Euro Effect on Trade is not as Large as Commonly Thought. Oxford Bulletin of Economics and Statistics, 69, 473-496 [in English].

11. Johnson, Omotunde (1976). The exchange rate as an Instrument if Policy in a Developing Country. IMF Staff Papers [in English].

12. Kreinin, M. (1977). The Effect of Exchange Rate Changes on the Prices and Volume of Foreign Trade. IMF Staff Papers. (Vol. 24). Issue 2, 297-329 [in English].

13. Bhagwat, A., \& Onitsuka, Y. (1974). Export-Import Responses to Devaluation. IMF Staff Papers [in English].

14. Ridler, D. \& Yandle, C. (1972). A Simplified Method for Analyzing the Effects of Exchange Rate Changes on Exports of a Primary Commodity. IMF Staff Papers [in English].

15. Little, I. M. D., Cooper, R., Corden, W. M., \& Rajapatisani, S. (1993). Boom, Crisis and Adjustment: the Macroeconomic Experience of Developing Countries. Oxford University Press [in English].

16. Fleissig, A., \& Grennes, T. (1994). The Real Exchange Rate Conundrum: The Case of Central America. World Development. (Vol. 22) [in English].

17. Sadoulet, E., \& De Janvry, A. (1995). Quantitative Development Analysis. John Hopkins University Press [in English].

18. DE Vries, M. G. (1968). Exchange Depreciation in Developing Countries. IMF Staff Papers [in English].

19. Edwards, S. (1988). Exchange Rate Misalignment in Developing Countries. John Hopkins University Press [in English].

20. Sadoulet, E., \& Janvry, A. (1995). Quantitative Development Policy Analysis. Johns Hopkins University Press [in English].

21. Imf. Finance and Development (1995). IMF March [in English].

22. The world bank operations UNIT (1992). Trade Policy Reforms under Adjustment Programs. World Bank [in English].

23. Ruda, Y., \& Repko, M. (2017). The Term of Valeria Hontareva: Monetary Policy in the Times of Unprecedented Challenges. Voxukraine [in English].

24. Khemani, R. S., \& Shapiro, D. M. (1993). Glossary of Industrial Organisation Economics and Competition Law. OECD [in English].

25. Goldstein, M., \& Khan, M. S. (1985). Income and price effects in foreign trade in Handbook of International Economics. (Vol. 2), 1041-1105 [in English].

26. Khan, M., \& Ostry, J. (1992). Real Exchange Rate Responses to External and Policy Shocks. World Development, September [in English].

The article submitted to editor's office on 10.03.2020. 
Хелласр М. Ефект девальвації обмінного курсу Украӥни в торгівлі з $С С$.

Постановка проблеми. Україна у 2014 році підписала ПВЗВТ з Свропейським Союзом, сподіваючись, щэо негайно відбудеться значне збільшення експорту України до ЄС. Однак насправді товарообіг України за 3 роки після відкриття ринку ЄС фактично зменшився. Утім, Україна перейшла з системи контрольованих обмінних курсів, щяо діяли до 2014 року, до керованої плаваючої системи.

Аналіз останніх досліджень $\boldsymbol{i}$ публікацій. Оцінка валютного курсу Украӥни зорієнтована на попередню контрольовану систему та ї̈ недоліки й наслідки для економіки. Для проведення дослідження визначено подальший аналіз теоретичних $i$ фактичних наслідків девальвачії обмінного курсу (в результаті переходу від нерухомої до плаваючої системи).

Метою статті є дослідження впливу девальвації валюти Украӥни на експорт до СС у рамках ПВЗВТ, щзб побачити ступінь впливу на зміну в торгівлі внаслідок девальващії на відміну від покращених умов доступу на ринок ПВЗВТ.

Матеріали та методи. Методологічною основою статті стали методи аналізу та синтезу, статистичний аналіз і регресійне моделювання OLS. Дослідження, засноване на експортних даних з Свропейського Союзу на рівні продукиї, показниках Світового банку щэодо обмінного курсу та тексті Угоди про асоиіацію між Україною та СС.

Результати дослідження. У статті розглянуто, як впливає номінальний курс, реальний курс і мінливість курсу на торгівлю з СС. За результатами аналізу визначено, щзо девальваџія реального валютного курсу мала, як очікується, позитивний вплив на експорт Украӥни, проте номінальний курс і мінливість курсу на нього не вплинули. Проведення дослідження розділено за видами продукиї, сільського господарства, несільськогосподарських товарів і продуктів, щзо отримали вигоду від доступу на ринок у рамках ПВЗВТ.

Висновки. Результати дослідження показують, щу лібералізація гривні, що відбулася водночас із впровадженням ПВЗВТ в Украӥні у 2014 роиі має значний вплив та позитивний внесок у ефективність експорту України з СС. Однак набагато більший вплив спостерігався на сільськогосподарську продукцію, зокрема на основні товари з низькою доданою вартістю. Це дає змогу припустити, що інші бар'єри впливають на иі продукти з більшою доданою вартістю, які обмежують вплив, або що вони більше покладаються на імпортні вкладення, які водночас матимуть подорожчати через девальвачію.

Ключові слова: лібералізація торгівлі, поглиблена та всеосяжна зона вільної торгівлі, економічне зростання, регулювання валюти, режим валютного курсу, експорт, пільгові торговельні угоди. 